\title{
Papers
}

\section{How well does B-type natriuretic peptide predict death and cardiac events in patients with heart failure: systematic review}

\author{
J A Doust, E Pietrzak, A Dobson, P P Glasziou
}

\begin{abstract}
Objective To assess how well B-type natriuretic peptide (BNP) predicts prognosis in patients with heart failure.

Design Systematic review of studies assessing BNP for prognosis in patients with heart failure or asymptomatic patients.

Data sources Electronic searches of Medline and Embase from January 1994 to March 2004 and reference lists of included studies.

Study selection and data extraction We included all studies that estimated the relation between BNP measurement and the risk of death, cardiac death, sudden death, or cardiovascular event in patients with heart failure or asymptomatic patients, including initial values and changes in values in response to treatment. Multivariable models that included both BNP and left ventricular ejection fraction as predictors were used to compare the prognostic value of each variable. Two reviewers independently selected studies and extracted data.

Data synthesis 19 studies used BNP to estimate the relative risk of death or cardiovascular events in heart failure patients and five studies in asymptomatic patients. In heart failure patients, each $100 \mathrm{pg} / \mathrm{ml}$ increase was associated with a $35 \%$ increase in the relative risk of death. BNP was used in 35 multivariable models of prognosis. In nine of the models, it was the only variable to reach significance--that is, other variables contained no prognostic information beyond that of BNP. Even allowing for the scale of the variables, it seems to be a strong indicator of risk.

Conclusion Although systematic reviews of prognostic studies have inherent difficulties, including the possibility of publication bias, the results of the studies in this review show that BNP is a strong prognostic indicator for both asymptomatic patients and for patients with heart failure at all stages of disease.
\end{abstract}

\section{Introduction}

The clinical assessment of heart failure is notoriously difficult; it is difficult to determine which patients have heart failure and, once the diagnosis is established, to predict which patients are at risk of death or further cardiovascular events. Many studies have tried to determine which factors increase mortality and morbidity in patients with heart failure across a variety of clinical settings. Factors that have been shown to be predictors of mortality are increasing age, a history of diabetes mellitus or renal dysfunction, higher functional disability measures such as New York Heart Association class, lower left ventricular ejection fraction, lower sodium concentrations, lower body mass index, lower blood pressure, the presence of ankle oedema, and lower quality of life scores. ${ }^{1-4}$ However, none of these is a strong predictor, and so intense interest has emerged in the predictive value of B-type natriuretic peptide (BNP).

The natriuretic peptides are released by the heart in response to myocardial tension and increased intravascular volume and provide accurate tests for the diagnosis of heart failure compared with echocardiography or expert clinical consensus. ${ }^{5}$ In most countries, it is not currently standard clinical practice to measure these peptides to determine prognosis in patients with heart failure. Our aim in this study was to review systematically the literature to determine how well BNP or its precursor form, $\mathrm{N}$-terminal pro-brain natriuretic peptide (NT-proBNP), predict mortality and morbidity in patients with heart failure, and to determine if this varied with the clinical setting or severity of heart failure. We also wanted to compare BNP with other traditional prognostic indicators, such as left ventricular ejection fraction, New York Heart Association class, serum sodium concentrations, age, history of diabetes mellitus, peak oxygen uptake $\left(\mathrm{VO}_{2}\right)$, or a scoring system used to estimate the risk of death in patients awaiting heart transplantation, the heart failure survival score. ${ }^{4}$

\section{Methods}

We searched Medline and Embase from January 1994 to March 2004 for all studies of the prognostic value of BNP in patients with heart failure, including all stages of heart failure, all clinical settings, and all lengths of follow-up, with no restriction on the language of publication. We also included studies that had estimated the relation between BNP values and prognosis in "asymptomatic" patients. We excluded all studies conducted in patients with recent myocardial infarction because of the likely instability in the relation between BNP concentration and prognosis at this time. We also excluded studies that did not include a clear clinical end point, such as death, hospital admission, or further cardiovascular event. The search strategy included $17 \mathrm{MeSH}$ or text word terms for the condition "heart failure" and five $\mathrm{MeSH}$ terms for the diagnostic test "natriuretic peptides." The full strategy (see bmj.com) retrieved 861 citations. We subsequently checked the reference lists of primary studies and review articles identified by the search for further relevant studies.

Two reviewers (JAD, EP) checked the lists of abstracts and then the full papers for eligible studies and extracted data independently. Where they disagreed on inclusion or exclusion of a

The full search strategy is on bmj.com 
Table 1 B-type natriuretic peptide (continuous measures) to predict survival

\begin{tabular}{|c|c|c|c|c|c|c|c|c|c|c|c|}
\hline \multirow[b]{2}{*}{ Study } & \multirow{2}{*}{$\begin{array}{c}\text { Population (NYHA } \\
\text { class) }\end{array}$} & \multirow{2}{*}{$\begin{array}{l}\text { Diagnosis of heart } \\
\text { failure }\end{array}$} & \multirow{2}{*}{$\begin{array}{c}\text { Mean } \\
\text { age }\end{array}$} & \multirow{2}{*}{$\begin{array}{c}\text { No of } \\
\text { participants } \\
\text { (events) }\end{array}$} & \multirow{2}{*}{$\begin{array}{c}\text { Mean } \\
\text { follow-up } \\
\text { in years }\end{array}$} & \multirow{2}{*}{$\begin{array}{c}\text { Consecutive } \\
\text { cohort }\end{array}$} & \multicolumn{2}{|c|}{$\begin{array}{l}\text { Ascertainment of } \\
\text { outcome }\end{array}$} & \multirow[b]{2}{*}{ Model } & \multirow[b]{2}{*}{ Units of BNP } & \multirow{2}{*}{$\begin{array}{c}\text { Hazard ratio } \\
(95 \% \mathrm{CI})\end{array}$} \\
\hline & & & & & & & Blinded & Objective & & & \\
\hline $\begin{array}{l}\text { Tsutamoto } \\
\text { et al, } \\
1999^{7}\end{array}$ & $\begin{array}{l}\text { Patients with heart } \\
\text { failure undergoing } \\
\text { cardiac } \\
\text { catheterisation (I } \\
\text { and II) }\end{array}$ & $\begin{array}{l}\text { Left ventricular } \\
\text { ejection fraction }<45 \% \\
\text { by ventriculography }\end{array}$ & 59 & $290(24)$ & 1.4 & Yes & $\begin{array}{l}\text { Not } \\
\text { reported }\end{array}$ & Yes & $\begin{array}{l}\text { Adjusted Cox } \\
\text { regression }\end{array}$ & Per 100 pg/ml & $1.5(1.3$ to 1.8$)$ \\
\hline $\begin{array}{l}\text { Wijeysundera } \\
\text { et al, } \\
2003^{8}\end{array}$ & $\begin{array}{l}\text { Patients enrolled in } \\
\text { PRAISE-2 trial and } \\
\text { surviving to } 6 \\
\text { months (III and IV) }\end{array}$ & $\begin{array}{l}\text { Left ventricular } \\
\text { ejection fraction }<30 \%\end{array}$ & 58 & 181 & 1.9 & Subset of trial & $\begin{array}{l}\text { Not } \\
\text { reported }\end{array}$ & Yes & $\begin{array}{l}\text { Unadjusted } \\
\text { Cox } \\
\text { regression }\end{array}$ & Per 100 pg/ml & $1.5(1.2$ to 1.8$)$ \\
\hline $\begin{array}{l}\text { Bettencourt } \\
\text { et al, } \\
2000^{9}\end{array}$ & $\begin{array}{l}\text { Patients with mild } \\
\text { to moderate heart } \\
\text { failure referred to } \\
\text { heart failure clinic } \\
\text { (I-III) }\end{array}$ & Clinical assessment & 67 & $139(39)$ & 1.5 & Yes & $\begin{array}{l}\text { Not } \\
\text { reported }\end{array}$ & Yes & $\begin{array}{l}\text { Adjusted Cox } \\
\text { regression }\end{array}$ & Per 100 pg/ml & $\begin{array}{c}1.01 \\
(1.00 \text { to } 1.02)^{*}\end{array}$ \\
\hline $\begin{array}{l}\text { Tsutamoto } \\
\text { et al, } \\
2001^{10}\end{array}$ & $\begin{array}{l}\text { Patients with } \\
\text { symptomatic heart } \\
\text { failure seen in } \\
\text { internal medicine } \\
\text { clinic (II-IV) }\end{array}$ & $\begin{array}{l}\text { Left ventricular } \\
\text { ejection fraction }<45 \% \\
\text { by ventriculography }\end{array}$ & 60 & 96 (29) & 3 & Yes & $\begin{array}{l}\text { Not } \\
\text { reported }\end{array}$ & Yes & $\begin{array}{l}\text { Adjusted Cox } \\
\text { regression }\end{array}$ & Per 100 pg/ml & 1.2 (1.1 to 1.3$)$ \\
\hline $\begin{array}{l}\text { Tsutamoto } \\
\text { et al, } \\
1997^{11}\end{array}$ & $\begin{array}{l}\text { Patients admitted } \\
\text { with heart failure } \\
\text { (II-IV) }\end{array}$ & $\begin{array}{l}\text { Left ventricular } \\
\text { ejection fraction }<45 \% \\
\text { by ventriculography }\end{array}$ & 60 & $85(25)$ & 2 & Not stated & $\begin{array}{c}\text { Not } \\
\text { reported }\end{array}$ & Yes & $\begin{array}{l}\text { Adjusted Cox } \\
\text { regression }\end{array}$ & Per 100 pg/ml & $1.3(1.1$ to 1.5$)$ \\
\hline $\begin{array}{l}\text { Imamura } \\
\text { et al, } \\
2001^{12}\end{array}$ & $\begin{array}{l}\text { Patients enrolled in } \\
\text { a study of } \\
\text { I-123-MIBG (II-IV) }\end{array}$ & $\begin{array}{l}\text { Left ventricular } \\
\text { ejection fraction }<40 \% \\
\text { by radionuclide } \\
\text { angiography or } \\
\text { echocardiography }\end{array}$ & 63 & 171 (11) & 2.2 & Subset of trial & $\begin{array}{c}\text { Not } \\
\text { reported }\end{array}$ & Yes & $\begin{array}{l}\text { Unadjusted } \\
\text { Cox } \\
\text { regression }\end{array}$ & Per 100 pg/ml & 1.6 (1.2 to2.2) \\
\hline
\end{tabular}

The Shionogi test was used to measure BNP in all studies except that by Wijeysundera et al, for which the test was not reported.

The outcome was death in all studies except that by Imamura et al, where it was cardiac death.

Follow-up was complete in all studies.

${ }^{*}$ Confidence interval calculated by authors from published $\mathrm{P}$ value.

NYMA=New York Heart Association.

study or data extraction, the differences were resolved by data were extracted from multivariable regression models of consensus or by discussion with a third reviewer. Where possible, prognosis.

Table 2 B-type natriuretic peptide (dichotomous measures) to predict survival

\begin{tabular}{|c|c|c|c|c|c|c|c|c|c|c|c|c|c|}
\hline \multirow[b]{2}{*}{ Study } & \multirow{2}{*}{$\begin{array}{l}\text { Population } \\
\text { (NYHA class) }\end{array}$} & \multirow{2}{*}{$\begin{array}{l}\text { Diagnosis of } \\
\text { heart failure }\end{array}$} & \multirow{2}{*}{$\begin{array}{c}\text { Mean } \\
\text { age }\end{array}$} & \multirow[b]{2}{*}{ BNP test } & \multirow[b]{2}{*}{ Outcome } & \multirow{2}{*}{$\begin{array}{c}\text { No of } \\
\text { participants } \\
\text { (events) }\end{array}$} & \multirow{2}{*}{$\begin{array}{l}\text { Mean } \\
\text { follow- } \\
\text { up in } \\
\text { years }\end{array}$} & \multirow{2}{*}{$\begin{array}{c}\text { Consecutive } \\
\text { cohort }\end{array}$} & \multicolumn{2}{|c|}{$\begin{array}{l}\text { Ascertainment of } \\
\text { outcome }\end{array}$} & \multirow[b]{2}{*}{ Model } & \multirow[b]{2}{*}{ Units of BNP } & \multirow{2}{*}{$\begin{array}{l}\text { Relative } \\
\text { measure of } \\
\text { survival } \\
(95 \% \mathrm{CI})\end{array}$} \\
\hline & & & & & & & & & Blinded & Objective & & & \\
\hline $\begin{array}{l}\text { Anand et } \\
\text { al, } \\
2003^{13}\end{array}$ & $\begin{array}{l}\text { Patients enrolled } \\
\text { in Val-HeFT trial } \\
(\mathrm{I}-\mathrm{IV})\end{array}$ & $\begin{array}{l}\text { Left ventricular } \\
\text { ejection fraction } \\
<40 \% \text { and/or left } \\
\text { ventricular } \\
\text { internal diastolic } \\
\text { diameter/body } \\
\text { surface area } \geq 2.9 \\
\mathrm{~cm} / \mathrm{m}^{2}\end{array}$ & $\begin{array}{l}\text { Not } \\
\text { reported }\end{array}$ & Shionogi & Death & $\begin{array}{l}4305 \\
(832)\end{array}$ & $2-3$ & $\begin{array}{c}\text { Subset of } \\
\text { trial }\end{array}$ & $\begin{array}{c}\text { Not } \\
\text { reported }\end{array}$ & Yes & $\begin{array}{l}\text { Adjusted } \\
\text { Cox } \\
\text { regression }\end{array}$ & $>97 \mathrm{pg} / \mathrm{ml}$ & $\begin{array}{c}\text { Hazard ratio } \\
2.1(1.8 \text { to } \\
2.4)\end{array}$ \\
\hline $\begin{array}{l}\text { Richards } \\
\text { et al, } \\
2001^{14}\end{array}$ & $\begin{array}{l}\text { Patients with LV } \\
\text { dysfunction } \\
\text { enrolled in a trial } \\
\text { of carvedilol } \\
\text { (I-III) }\end{array}$ & $\begin{array}{l}\text { Left ventricular } \\
\text { ejection fraction } \\
<45 \% \text { on } \\
\text { ventriculography }\end{array}$ & $\begin{array}{l}\text { Not } \\
\text { reported }\end{array}$ & NT-proBNP & Death & 297 (35) & 1.5 & $\begin{array}{c}\text { Subset of } \\
\text { trial }\end{array}$ & $\begin{array}{l}\text { Not } \\
\text { reported }\end{array}$ & Yes & $\begin{array}{l}\text { Unadjusted } \\
\text { relative } \\
\text { risk }\end{array}$ & $\begin{array}{l}\text { NT-proBNP } \\
>550 \mathrm{pg} / \mathrm{ml}\end{array}$ & $\begin{array}{c}\text { Relative risk } \\
4.7(2.0 \text { to } \\
10.9)\end{array}$ \\
\hline $\begin{array}{l}\text { Vrtovec et } \\
\text { al, } \\
2002^{15}\end{array}$ & $\begin{array}{l}\text { Patients referred } \\
\text { to heart failure } \\
\text { clinic (III-IV) }\end{array}$ & Not reported & 67 & Biosite & Death & 241 (46) & 0.5 & Yes & $\begin{array}{c}\text { Not } \\
\text { reported }\end{array}$ & Yes & $\begin{array}{l}\text { Adjusted } \\
\text { Cox } \\
\text { regression }\end{array}$ & $\begin{array}{l}>1000 \mathrm{pg} / \mathrm{ml} \\
\text { (relative to } \\
>400 \mathrm{pg} / \mathrm{ml} \text { ) }\end{array}$ & $\begin{array}{c}\text { Hazard ratio } \\
2.0(1.2 \text { to } \\
3.4)\end{array}$ \\
\hline $\begin{array}{l}\text { Gardner et } \\
\text { al, } \\
2003^{16}\end{array}$ & $\begin{array}{l}\text { Patients referred } \\
\text { for consideration } \\
\text { of transplantation } \\
\text { II-IV) }\end{array}$ & $\begin{array}{l}\text { Left ventricular } \\
\text { ejection fraction } \\
\leq 35 \%\end{array}$ & 50 & $\begin{array}{c}\text { NT-proBNP } \\
\text { (Roche) }\end{array}$ & Death & $142(20)$ & $\begin{array}{l}\text { Median } \\
1.0\end{array}$ & Yes & $\begin{array}{c}\text { Not } \\
\text { reported }\end{array}$ & Yes & $\begin{array}{c}\text { Unadjusted } \\
\text { odds ratio }\end{array}$ & $>1490 \mathrm{pg} / \mathrm{ml}$ & $\begin{array}{c}\text { Odds ratio } \\
5.0(1.6 \text { to } \\
15.9)\end{array}$ \\
\hline $\begin{array}{l}\text { Harrison } \\
\text { et al, } \\
2002^{17}\end{array}$ & $\begin{array}{l}\text { Patients } \\
\text { presenting with } \\
\text { dyspnoea to } \\
\text { emergency } \\
\text { department (N/A) }\end{array}$ & $\begin{array}{l}\text { Excluded trauma, } \\
\text { unstable angina } \\
\text { or myocardial } \\
\text { infarction }\end{array}$ & 65 & Biosite & $\begin{array}{l}\text { Cardiac } \\
\text { death }\end{array}$ & $325(23)$ & 0.5 & No & Yes & Yes & $\begin{array}{l}\text { Unadjusted } \\
\text { relative } \\
\text { risk }\end{array}$ & $>230 \mathrm{pg} / \mathrm{ml}$ & $\begin{array}{c}\text { Relative risk } \\
37.9(5.7 \text { to } \\
755.8)\end{array}$ \\
\hline $\begin{array}{l}\text { Vrtovec et } \\
\text { al, } \\
2002^{15}\end{array}$ & $\begin{array}{l}\text { Patients referred } \\
\text { to heart failure } \\
\text { clinic (III-IV) }\end{array}$ & Not reported & 67 & Biosite & $\begin{array}{c}\text { Cardiac } \\
\text { death }\end{array}$ & 241 (42) & 0.5 & Yes & $\begin{array}{c}\text { Not } \\
\text { reported }\end{array}$ & Yes & $\begin{array}{l}\text { Adjusted } \\
\text { Cox } \\
\text { regression }\end{array}$ & $\begin{array}{l}>1000 \mathrm{pg} / \mathrm{ml} \\
\text { (relative to } \\
>400 \mathrm{pg} / \mathrm{ml} \text { ) }\end{array}$ & $\begin{array}{c}\text { Hazard ratio } \\
1.8(1.0 \text { to } \\
3.1)\end{array}$ \\
\hline $\begin{array}{c}\text { Yu et al, } \\
1999^{18}\end{array}$ & $\begin{array}{l}\text { Patients admitted } \\
\text { for heart failure } \\
\text { (II-IV) }\end{array}$ & $\begin{array}{l}\text { Left ventricular } \\
\text { ejection fraction } \\
\leq 50 \%\end{array}$ & 61 & Peninsula & $\begin{array}{l}\text { Cardiac } \\
\text { death }\end{array}$ & 91 (19) & 1 & Yes & $\begin{array}{c}\text { Not } \\
\text { reported }\end{array}$ & Yes & $\begin{array}{l}\text { Unadjusted } \\
\text { relative } \\
\text { risk }\end{array}$ & $>165 \mathrm{pg} / \mathrm{ml}$ & $\begin{array}{c}\text { Relative risk } \\
3.4(1.4 \text { to } \\
8.4)\end{array}$ \\
\hline
\end{tabular}

Follow-up was complete in all studies except for that by Yu et al, where five patients were lost to follow up. 
Table 3 Change in B-type natriuretic peptide to predict survival

\begin{tabular}{|c|c|c|c|c|c|c|c|c|c|c|c|}
\hline \multirow[b]{2}{*}{ Study } & \multirow{2}{*}{$\begin{array}{l}\text { Population } \\
\text { (NYHA class) }\end{array}$} & \multirow{2}{*}{$\begin{array}{l}\text { Diagnosis } \\
\text { of heart } \\
\text { failur }\end{array}$} & \multirow{2}{*}{$\begin{array}{l}\text { Mean } \\
\text { age }\end{array}$} & \multirow{2}{*}{$\begin{array}{l}\text { No of } \\
\text { participants } \\
\text { (events) }\end{array}$} & \multirow{2}{*}{$\begin{array}{l}\text { Mean } \\
\text { follow- } \\
\text { up in } \\
\text { years }\end{array}$} & \multirow{2}{*}{$\begin{array}{c}\text { Consecutive } \\
\text { cohort }\end{array}$} & \multicolumn{2}{|c|}{$\begin{array}{l}\text { Ascertainment of } \\
\text { outcome }\end{array}$} & \multirow[b]{2}{*}{ Model } & \multirow[b]{2}{*}{ Units of BNP } & \multirow{2}{*}{$\begin{array}{l}\text { Relative measure of survival } \\
\qquad(95 \% \mathrm{CI})\end{array}$} \\
\hline & & & & & & & Blinded & Objective & & & \\
\hline $\begin{array}{l}\text { Anand et al, } \\
2003^{13}\end{array}$ & $\begin{array}{l}\text { Patients } \\
\text { enrolled in } \\
\text { Val-HeFT trial } \\
(\mathrm{I}-\mathrm{IV})\end{array}$ & $\begin{array}{l}\text { Left } \\
\text { ventricular } \\
\text { ejection } \\
\text { fraction } \\
<40 \% \\
\text { and/or left } \\
\text { ventricular } \\
\text { internal } \\
\text { diastolic } \\
\text { diameter/ } \\
\text { body } \\
\text { surface area } \\
\geq 2.9 \mathrm{~cm} / \mathrm{m}^{2}\end{array}$ & $\begin{array}{c}\text { Not } \\
\text { reported }\end{array}$ & $3740(592)$ & $2-3$ & Subset of trial & $\begin{array}{l}\text { Not } \\
\text { reported }\end{array}$ & Yes & $\begin{array}{l}\text { Adjusted } \\
\text { Cox } \\
\text { regression }\end{array}$ & $\begin{array}{l}\text { Quarter changes } \\
\text { after } 4 \text { months } \\
\text { (relative to } \\
\text { greatest change } \\
-45 \%)^{\star}\end{array}$ & $\begin{array}{l}-45 \text { to }-13 \% \text { : relative risk } 1.3 \\
(1.0 \text { to } 1.7) \\
-13 \text { to }+30 \% \text { : relative risk } 1.4 \\
(1.0 \text { to } 1.7) \\
+30 \% \text { : relative risk } 1.9 \text { ( } 1.5 \text { to } \\
2.4 \text { ) }\end{array}$ \\
\hline $\begin{array}{l}\text { Wijeysundera } \\
\text { et al, } \\
2003^{8}\end{array}$ & $\begin{array}{l}\text { Patients } \\
\text { enrolled in } \\
\text { PRAISE-2 trial } \\
\text { and surviving } \\
\text { to } 6 \text { months } \\
\text { (III and IV) }\end{array}$ & $\begin{array}{l}\text { Left } \\
\text { ventricular } \\
\text { ejection } \\
\text { fraction } \\
<30 \%\end{array}$ & 58 & $121(26)$ & 1.9 & Subset of trial & $\begin{array}{c}\text { Not } \\
\text { reported }\end{array}$ & Yes & $\begin{array}{l}\text { Adjusted } \\
\text { Cox } \\
\text { regression }\end{array}$ & $\begin{array}{l}\text { Decrease at } 6 \\
\text { months }\end{array}$ & $\begin{array}{l}\text { Hazard ratio } 0.99 \text { (0.98 to } \\
0.99)\end{array}$ \\
\hline $\begin{array}{l}\text { Matsui et } \\
\text { al, } 2002^{19}\end{array}$ & $\begin{array}{l}\text { Patients } \\
\text { admitted for } \\
\text { dilated } \\
\text { cardiomyopathy } \\
\text { and surviving } \\
6 \text { months } \\
\text { (II-IV) }\end{array}$ & $\begin{array}{l}\text { Left } \\
\text { ventricular } \\
\text { ejection } \\
\text { fraction } \\
<45 \%\end{array}$ & 55 & 74 (12) & 2 & Yes & $\begin{array}{l}\text { Not } \\
\text { reported }\end{array}$ & Yes & $\begin{array}{l}\text { Unadjusted } \\
\text { relative risk }\end{array}$ & $\begin{array}{l}>170 \mathrm{pg} / \mathrm{ml} \text { after } \\
6 \text { months of } \\
\text { treatment }\end{array}$ & $\begin{array}{l}\text { Relative risk } 11.8 \text { (2.8 to } \\
49.6 \text { ) }\end{array}$ \\
\hline $\begin{array}{l}\text { Maeda et al, } \\
2000^{20}\end{array}$ & $\begin{array}{l}\text { Patients } \\
\text { admitted for } \\
\text { heart failure } \\
\text { and surviving } \\
\text { to } 3 \text { month } \\
\text { (III-IV)s }\end{array}$ & $\begin{array}{l}\text { Left } \\
\text { ventricular } \\
\text { ejection } \\
\text { fraction } \\
<45 \%\end{array}$ & 64 & $102(26)$ & 2.2 & Yes & Yes & $\begin{array}{l}\text { Not } \\
\text { reported }\end{array}$ & $\begin{array}{l}\text { Unadjusted } \\
\text { relative risk }\end{array}$ & $\begin{array}{l}>240 \mathrm{pg} / \mathrm{ml} \text { after } \\
3 \text { months of } \\
\text { treatment }\end{array}$ & Relative risk 4.4 (2.0 to 9.5 ) \\
\hline
\end{tabular}

The Shionogi test was used to measure BNP in all studies except that by Wijeysundera et al, for which the test was not reported.

The outcome was death in all studies except that by Maeda et al, where it was cardiac death.

Follow-up was complete in all studies.

${ }^{*}$ The response to treatment has been divided into four quarters. Each group has been compared with the quarter that had the greatest reduction in BNP after treatment-that is, patients with a reduction in their BNP value of more than $45 \%$.

We assessed the quality of the included studies by determining how patients were selected for the study (in particular, whether the study was a prospective and consecutive cohort of patients), if follow-up of patients was complete and sufficiently long, and if the ascertainment of the end points was blinded and objective. $^{6}$ We assessed the representativeness of each of the included studies by determining the clinical setting, the spectrum of the patients included in each study, the method for diagnosing heart failure, and the age of the patients. We also extracted data on study size and number of outcomes, the method for measur- ing BNP, the type of statistical model used, and the way in which BNP was modelled in the studies.

The most common form of analysis for prognostic studies is the Cox proportional hazards model. Such models measure the hazard ratio-the relative effect of a predictive factor on an outcome-by assuming that this relation is constant over time. To combine the data from as many studies as possible, we assumed that where the outcome is relatively rare, the relative risk or odds ratio approximates the hazard ratio. For the outcome of death, we planned to combine estimates of the hazard ratio, odds ratio,

Table 4 B-type natriuretic peptide (continuous measures) to predict cardiovascular events

\begin{tabular}{|c|c|c|c|c|c|c|c|c|c|c|c|c|}
\hline \multirow[b]{2}{*}{ Study } & \multirow{2}{*}{$\begin{array}{l}\text { Population } \\
\text { (NYHA class) }\end{array}$} & \multirow{2}{*}{$\begin{array}{l}\text { Diagnosis of heart } \\
\text { failure }\end{array}$} & \multirow{2}{*}{$\begin{array}{c}\text { Mean } \\
\text { age in } \\
\text { eyars }\end{array}$} & \multirow[b]{2}{*}{ Outcome } & \multirow{2}{*}{$\begin{array}{l}\text { No of } \\
\text { participants } \\
\text { (events) }\end{array}$} & \multirow{2}{*}{$\begin{array}{c}\text { Mean } \\
\text { follow-up in } \\
\text { years }\end{array}$} & \multirow{2}{*}{$\begin{array}{c}\text { Consecutive } \\
\text { cohort }\end{array}$} & \multicolumn{2}{|c|}{$\begin{array}{l}\text { Ascertainment of } \\
\text { outcome }\end{array}$} & \multirow[b]{2}{*}{ Model } & \multirow{2}{*}{$\begin{array}{l}\text { Units of } \\
\text { BNP }\end{array}$} & \multirow{2}{*}{$\begin{array}{c}\text { Hazard ratio } \\
(95 \% \text { CI) }\end{array}$} \\
\hline & & & & & & & & Blinded & Objective & & & \\
\hline $\begin{array}{l}\text { Imamura } \\
\text { et al, } \\
2001^{12}\end{array}$ & $\begin{array}{l}\text { Patients } \\
\text { enrolled in a } \\
\text { study of } \\
\text { I-123-MIBG } \\
\text { (II-IV) }\end{array}$ & $\begin{array}{l}\text { Left ventricular } \\
\text { ejection fraction } \\
<40 \% \text { by } \\
\text { radionuclide } \\
\text { angiography or } \\
\text { echocardiography }\end{array}$ & 63 & $\begin{array}{l}\text { Death or } \\
\text { hospitalisation }\end{array}$ & 171 (27) & 2.2 & $\begin{array}{l}\text { Subset of } \\
\text { trial }\end{array}$ & $\begin{array}{l}\text { Not } \\
\text { reported }\end{array}$ & Yes & $\begin{array}{l}\text { Unadjusted } \\
\text { Cox } \\
\text { regression }\end{array}$ & $\begin{array}{l}\text { Per } 100 \\
\mathrm{pg} / \mathrm{ml}\end{array}$ & 1.8 (1.5 to 2.0$)$ \\
\hline $\begin{array}{l}\text { Koglin et } \\
\text { al, } \\
2001^{21}\end{array}$ & $\begin{array}{l}\text { Patients } \\
\text { referred to HF } \\
\text { clinic (I-IV) }\end{array}$ & Not reported & 51 & $\begin{array}{l}\text { Death or } \\
\text { deterioration }\end{array}$ & 78 (25) & Median 1.1 & $\begin{array}{l}\text { Not } \\
\text { reported }\end{array}$ & $\begin{array}{l}\text { Not } \\
\text { reported }\end{array}$ & No & $\begin{array}{l}\text { Unadjusted } \\
\text { Cox } \\
\text { regression }\end{array}$ & $\begin{array}{l}\text { Per } 100 \\
\mathrm{pg} / \mathrm{ml}\end{array}$ & 1.5 (1.2 to 1.8$)$ \\
\hline $\begin{array}{r}\text { Tamura, } \\
2001^{22}\end{array}$ & $\begin{array}{l}\text { Patients older } \\
\text { than } 65 \\
\text { admitted for } \\
\text { first episode of } \\
\text { HF (I-IV) }\end{array}$ & Clinical assessment & 78 & $\begin{array}{l}\text { Cardiac death } \\
\text { or worsening } \\
\text { heart failure or } \\
\text { myocardial } \\
\text { infarction }\end{array}$ & 48 (12) & 0.9 & Yes & $\begin{array}{l}\text { Not } \\
\text { reported }\end{array}$ & $\begin{array}{l}\text { Not } \\
\text { reported }\end{array}$ & $\begin{array}{l}\text { Adjusted } \\
\text { Cox } \\
\text { regression }\end{array}$ & $\begin{array}{c}\text { Per } \log _{10} \\
\text { BNP }\end{array}$ & $2.7(1.2 \text { to } 5.8)^{\star}$ \\
\hline
\end{tabular}

The Shionogi test was used to measure BNP in all studies.

Follow-up was complete in all studies.

${ }^{*}$ Confidence interval calculated by authors from published $\mathrm{P}$ value. 
Table 5 B-type natriuretic peptide (dichotomous measures) to predict cardiovascular events

\begin{tabular}{|c|c|c|c|c|c|c|c|c|c|c|c|c|c|}
\hline \multirow[b]{2}{*}{ Study } & \multirow{2}{*}{$\begin{array}{l}\text { Population (NYHA } \\
\text { class) }\end{array}$} & \multirow{2}{*}{$\begin{array}{l}\text { Diagnosis of } \\
\text { heart failure }\end{array}$} & \multirow{2}{*}{$\begin{array}{c}\text { Mean } \\
\text { age }\end{array}$} & \multirow[b]{2}{*}{ BNP test } & \multirow[b]{2}{*}{ Outcome } & \multirow{2}{*}{$\begin{array}{c}\text { No of } \\
\text { participants } \\
\text { (events) }\end{array}$} & \multirow{2}{*}{$\begin{array}{c}\text { Mean } \\
\text { follow-up } \\
\text { in years }\end{array}$} & \multirow{2}{*}{$\begin{array}{c}\text { Consecutive } \\
\text { cohort }\end{array}$} & \multicolumn{2}{|c|}{$\begin{array}{c}\text { Ascertainment of } \\
\text { outcome }\end{array}$} & \multirow[b]{2}{*}{ Model } & \multirow{2}{*}{$\begin{array}{c}\text { Units } \\
\text { of BNP }\end{array}$} & \multirow{2}{*}{$\begin{array}{l}\text { Relative } \\
\text { measure of } \\
\text { risk of } \\
\text { cardiovascular } \\
\text { event (95\% } \\
\text { CI) }\end{array}$} \\
\hline & & & & & & & & & Blinded & Objective & & & \\
\hline $\begin{array}{l}\text { Anand et } \\
\text { al, } \\
2003^{13}\end{array}$ & $\begin{array}{l}\text { Patients enrolled } \\
\text { in Val-HeFT trial } \\
(\text { I-IV) }\end{array}$ & $\begin{array}{l}\text { Left ventricular } \\
\text { ejection fraction } \\
<40 \% \text { and/or left } \\
\text { ventricular internal } \\
\text { diastolic } \\
\text { diameter/body } \\
\text { surface area } \geq 2.9 \\
\mathrm{~cm} / \mathrm{m} 2\end{array}$ & $\begin{array}{c}\text { Not } \\
\text { reported }\end{array}$ & Shionogi & $\begin{array}{l}\text { Death or } \\
\text { hospitalisation }\end{array}$ & $\begin{array}{l}4305 \\
(1309)\end{array}$ & $2-3$ & $\begin{array}{c}\text { Subset of } \\
\text { trial }\end{array}$ & $\begin{array}{c}\text { Not } \\
\text { reported }\end{array}$ & Yes & $\begin{array}{l}\text { Adjusted } \\
\text { Cox } \\
\text { regression }\end{array}$ & $\begin{array}{l}>97 \\
\mathrm{pg} / \mathrm{ml}\end{array}$ & $\begin{array}{c}\text { Hazard ratio } \\
2.2(2.0 \text { to } \\
2.5)\end{array}$ \\
\hline $\begin{array}{l}\text { Harrison } \\
\text { et al, } \\
2002^{17}\end{array}$ & $\begin{array}{l}\text { Patients } \\
\text { presenting with } \\
\text { dyspnoea to } \\
\text { emergency } \\
\text { department (N/A) }\end{array}$ & $\begin{array}{l}\text { Excluded trauma, } \\
\text { unstable angina, } \\
\text { or myocardial } \\
\text { infarction }\end{array}$ & 65 & Biosite & $\begin{array}{l}\text { Cardiac } \\
\text { death } \\
\text { hospitalisation }\end{array}$ & $325(86)$ & 0.5 & No & Yes & Yes & $\begin{array}{l}\text { Unadjusted } \\
\text { relative } \\
\text { risk }\end{array}$ & $\begin{array}{l}>230 \\
\mathrm{pg} / \mathrm{ml}\end{array}$ & $\begin{array}{c}\text { Relative risk } \\
4.5(2.9 \text { to } \\
6.9)\end{array}$ \\
\hline $\begin{array}{l}\text { Harrison } \\
\text { et al, } \\
2002^{17}\end{array}$ & $\begin{array}{l}\text { Patients } \\
\text { presenting with } \\
\text { dyspnoea to } \\
\text { emergency } \\
\text { department (N/A) }\end{array}$ & $\begin{array}{l}\text { Excluded trauma, } \\
\text { unstable angina, } \\
\text { or myocardial } \\
\text { infarction }\end{array}$ & 65 & Biosite & $\begin{array}{l}\text { Death due to } \\
\text { heart failure } \\
\text { or } \\
\text { hospitalisation }\end{array}$ & $324(50)$ & 0.5 & No & Yes & Yes & $\begin{array}{l}\text { Unadjusted } \\
\text { relative } \\
\text { risk }\end{array}$ & $\begin{array}{l}>230 \\
\mathrm{pg} / \mathrm{ml}\end{array}$ & $\begin{array}{c}\text { Relative risk } \\
15.5(6.2 \text { to } \\
43.7)\end{array}$ \\
\hline $\begin{array}{l}\text { Harrison } \\
\text { et al, } \\
2002^{17}\end{array}$ & $\begin{array}{l}\text { Patients } \\
\text { presenting with } \\
\text { dyspnoea to } \\
\text { emergency } \\
\text { department (N/A) }\end{array}$ & $\begin{array}{l}\text { Excluded trauma, } \\
\text { unstable angina, } \\
\text { or myocardial } \\
\text { infarction }\end{array}$ & 65 & Biosite & $\begin{array}{l}\text { Death due to } \\
\text { heart failure } \\
\text { or } \\
\text { hospitalisation }\end{array}$ & $324(50)$ & 0.5 & No & Yes & Yes & $\begin{array}{l}\text { Unadjusted } \\
\text { relative } \\
\text { risk }\end{array}$ & $\begin{array}{l}>480 \\
\mathrm{pg} / \mathrm{ml}\end{array}$ & $\begin{array}{c}\text { Relative risk } \\
8.2(4.7 \text { to } \\
14.3)\end{array}$ \\
\hline $\begin{array}{l}\text { Richards } \\
\text { et al, } \\
2001^{14}\end{array}$ & $\begin{array}{l}\text { Patients with left } \\
\text { ventricular } \\
\text { dysfunction } \\
\text { enrolled in a trial } \\
\text { of carvedilol (not } \\
\text { reported) }\end{array}$ & $\begin{array}{l}\text { Left ventricular } \\
\text { ejection fraction } \\
<45 \%\end{array}$ & $\begin{array}{c}\text { Not } \\
\text { reported }\end{array}$ & d & $\begin{array}{l}\text { Worsening } \\
\text { heart failure }\end{array}$ & 297 (108) & 1.5 & $\begin{array}{c}\text { Subset of } \\
\text { trial }\end{array}$ & $\begin{array}{c}\text { Not } \\
\text { reported }\end{array}$ & Yes & $\begin{array}{l}\text { Unadjusted } \\
\text { relative } \\
\text { risk }\end{array}$ & $\begin{array}{l}\mathrm{N}-\mathrm{BNP} \\
>550 \\
\mathrm{pg} / \mathrm{ml}\end{array}$ & $\begin{array}{c}\text { Relative risk } \\
1.8(1.3 \text { to } \\
2.5)\end{array}$ \\
\hline $\begin{array}{l}\text { Gardner et } \\
\text { al, } \\
2003^{16}\end{array}$ & $\begin{array}{l}\text { Patients with } \\
\text { advanced heart } \\
\text { failure referred for } \\
\text { consideration of } \\
\text { transplantation } \\
\text { (II-IV) }\end{array}$ & $\begin{array}{l}\text { Left ventricular } \\
\text { ejection } \\
\text { fraction } \leq 35 \%\end{array}$ & 50 & $\begin{array}{c}\text { NT-proBNP } \\
\text { (Roche) }\end{array}$ & $\begin{array}{l}\text { Death or } \\
\text { urgent } \\
\text { transplantation }\end{array}$ & $142(24)$ & $\begin{array}{l}\text { Median } \\
1.0\end{array}$ & Yes & $\begin{array}{c}\text { Not } \\
\text { reported }\end{array}$ & Yes & $\begin{array}{l}\text { Unadjusted } \\
\text { Cox } \\
\text { regression }\end{array}$ & $\begin{array}{l}\mathrm{N}-\mathrm{BNP} \\
>1490 \\
\mathrm{pg} / \mathrm{ml}\end{array}$ & $\begin{array}{l}\text { Odds ratio } \\
6.8(2.2 \text { to } \\
21.1)\end{array}$ \\
\hline $\begin{array}{l}\text { Ishii et al, } \\
2002^{23}\end{array}$ & $\begin{array}{l}\text { Patients admitted } \\
\text { for worsening } \\
\text { heart failure } \\
\text { (mean 3.5) }\end{array}$ & Not reported & 69 & Shionogi & $\begin{array}{l}\text { Cardiac } \\
\text { death or } \\
\text { hospitalisation }\end{array}$ & $98(37)$ & 1.2 & Yes & Yes & Yes & $\begin{array}{l}\text { Adjusted } \\
\text { Cox } \\
\text { regression }\end{array}$ & $\begin{array}{l}>440 \\
\mathrm{pg} / \mathrm{ml}\end{array}$ & $\begin{array}{c}\text { Relative risk } \\
2.18(1.22 \text { to } \\
3.90)\end{array}$ \\
\hline
\end{tabular}

Follow-up was complete in all studies.

or relative risk from studies by using comparable measures of BNP using the "meta" command of Stata, version 7.0 (Stata Corporation, Texas USA, 2001). This command also tests for the presence of heterogeneity.

\section{Results}

From the 861 citations, we identified 32 studies that assessed if BNP predicts death or cardiac events in patients with heart failure or in asymptomatic patients, either via estimating a relative measure of risk such as a hazard ratio, or by measuring the statistical significance of the $\mathrm{BNP}$ in a multivariable model of prognosis. ${ }^{7-38}$ We identified 19 studies that assessed the relative risk of death or cardiac events with rises in BNP in patients with heart failure and five studies in asymptomatic patients. ${ }^{26-30}$ Fourteen studies used BNP or NT-proBNP to predict the relative risk of death or cardiac death in heart failure patients (six used a continuous measure of $\mathrm{BNP},{ }^{7-12}$ six used a dichotomised measure, ${ }^{13-17}$ and four used a change in BNP over time ${ }^{8131920}$ ). Eleven studies used BNP or NT-proBNP to predict the risk of a cardiovascular event, most commonly death or hospital admission (three used a continuous measure of $\mathrm{BNP},{ }^{12}{ }^{22}$ five used a dichotomised measure, ${ }^{13} 1416161723$ and four used a change in BNP over time $^{13142025}$ ). Tables 1-6 show the results of each of these groups of studies.
In most studies, the primary outcome of interest was either death or cardiac death. These are reasonably objective end points, but it is difficult to assess from the study reports how completely patients in the studies were followed up and how completely outcomes were ascertained in each study. Three studies reported that some patients in the study were lost to follow-up; the remainder either reported complete follow-up or the calculations imply complete follow-up. A possibility exists of the selective reporting of outcomes or the biased reporting of only models with significant results.

The studies were conducted in various clinical settings and used various BNP tests. Although BNP and NT-proBNP seem to have skewed distributions, most of the models included BNP as either a continuous variable linearly related to the outcome or used a discrete cut-off point rather than a logarithmic transformation of the variable.

We combined the results of four of the five studies that estimated the relative risk of all cause mortality by using a continuous measure of BNP in a random effects model. ${ }^{7810}{ }^{11} \mathrm{We}$ excluded the study by Bettencourt et al because the published report did not provide results to sufficient accuracy to enable us to estimate a plausible hazard ratio. Pooling the other four studies gives an estimate of the relative risk of death per $100 \mathrm{pg} / \mathrm{ml}$ of $35 \%$ (95\% confidence interval $22 \%$ to $49 \%$, heterogeneity $\chi=6.3, \mathrm{df}=3, \mathrm{P}=0.096)$. Including the one study that used a 
Table 6 Change in B-type natriuretic peptide to predict cardiovascular events

\begin{tabular}{|c|c|c|c|c|c|c|c|c|c|c|c|c|c|}
\hline \multirow[b]{2}{*}{ Study } & \multirow[b]{2}{*}{$\begin{array}{l}\text { Population } \\
\text { (NYHA class) }\end{array}$} & \multirow[b]{2}{*}{$\begin{array}{l}\text { Diagnosis of } \\
\text { heart failure }\end{array}$} & \multirow[b]{2}{*}{$\begin{array}{c}\text { Mean } \\
\text { age }\end{array}$} & \multirow[b]{2}{*}{$\begin{array}{l}\text { BNP } \\
\text { test }\end{array}$} & \multirow[b]{2}{*}{ Outcome } & \multirow{2}{*}{$\begin{array}{c}\text { No of } \\
\text { participants } \\
\text { (events) }\end{array}$} & \multirow{2}{*}{$\begin{array}{l}\text { Mean } \\
\text { follow-up } \\
\text { in years }\end{array}$} & \multirow[b]{2}{*}{$\begin{array}{c}\text { Consecutive } \\
\text { cohort }\end{array}$} & \multicolumn{2}{|c|}{$\begin{array}{l}\text { Ascertainment of } \\
\text { outcome }\end{array}$} & \multirow[b]{2}{*}{ Model } & \multirow[b]{2}{*}{ Units of BNP } & \multirow{2}{*}{$\begin{array}{l}\text { Relative } \\
\text { measure of } \\
\text { risk of } \\
\text { cardiovascular } \\
\text { event }(95 \% \mathrm{Cl})\end{array}$} \\
\hline & & & & & & & & & Blinded & Objective & & & \\
\hline $\begin{array}{l}\text { Anand et } \\
\text { al, } \\
2003^{13}\end{array}$ & $\begin{array}{l}\text { Patients } \\
\text { enrolled in } \\
\text { Val-HeFT trial } \\
\text { of valsartan } \\
\text { (I-IV) }\end{array}$ & $\begin{array}{l}\text { Left ventricular } \\
\text { ejection } \\
\text { fraction }<40 \% \\
\text { and/or left } \\
\text { ventricular } \\
\text { internal } \\
\text { diastolic } \\
\text { diameter/body } \\
\text { surface area } \\
\geq 2.9 \mathrm{~cm} / \mathrm{m} 2 \\
\end{array}$ & $\begin{array}{l}\text { Not } \\
\text { reported }\end{array}$ & Shionogi & $\begin{array}{l}\text { Death or } \\
\text { hospitalisation }\end{array}$ & $3618(889)$ & 2 to 3 & $\begin{array}{l}\text { Subset of } \\
\text { trial }\end{array}$ & $\begin{array}{l}\text { Not } \\
\text { reported }\end{array}$ & Yes & $\begin{array}{l}\text { Adjusted } \\
\text { Cox } \\
\text { regression }\end{array}$ & $\begin{array}{l}\text { Quarter } \\
\text { changes after } 4 \\
\text { months } \\
\text { (relative to } \\
\text { greatest } \\
\text { change }=-45 \%)^{*}\end{array}$ & $\begin{array}{l}-45 \text { to }-13 \%: \\
\text { relative risk } 1.4 \\
(1.2 \text { to } 1.7) \\
-13 \text { to } 30 \%: \\
\text { relative risk } \\
1.67(1.36 \text { to } \\
2.04) \\
30 \% \text { : relative } \\
\text { risk } 2.20(1.80 \\
\text { to } 2.67)\end{array}$ \\
\hline $\begin{array}{l}\text { Cheng et } \\
\text { al, } \\
2001^{24}\end{array}$ & $\begin{array}{l}\text { Patients } \\
\text { admitted for } \\
\text { heart failure } \\
\text { (III) }\end{array}$ & $\begin{array}{l}\text { Clinical } \\
\text { assessment }\end{array}$ & 68 & Biosite & $\begin{array}{l}\text { Death and } \\
30 \text { day } \\
\text { readmission }\end{array}$ & 72 (22) & 1 month & No & $\begin{array}{l}\text { Not } \\
\text { reported }\end{array}$ & Yes & $\begin{array}{l}\text { Unadjusted } \\
\text { relative } \\
\text { risk }\end{array}$ & $\begin{array}{l}\text { Increase from } \\
\text { admission to } \\
\text { discharge }\end{array}$ & $\begin{array}{l}\text { Relative risk } \\
3.2 \text { (1.5 to } 6.8)\end{array}$ \\
\hline $\begin{array}{l}\text { Bettencourt } \\
\text { et al, } \\
2002^{31}\end{array}$ & $\begin{array}{l}\text { Patients } \\
\text { discharged } \\
\text { following } \\
\text { admission for } \\
\text { decompensated } \\
\text { heart failure } \\
\text { (II-IV) }\end{array}$ & Not reported & 71 & Biosite & $\begin{array}{l}\text { Death or } \\
\text { admission to } \\
\text { hospital for } \\
\text { cardiac } \\
\text { event }\end{array}$ & $43(20)$ & 0.5 & Yes & $\begin{array}{l}\text { Not } \\
\text { reported }\end{array}$ & Yes & $\begin{array}{l}\text { Unadjusted } \\
\text { Cox } \\
\text { regression }\end{array}$ & $\begin{array}{l}\text { Increase from } \\
\text { admission to } \\
\text { discharge }\end{array}$ & $\begin{array}{l}\text { Hazard ratio } \\
3.3 \text { (1.3 to } 8.8)\end{array}$ \\
\hline $\begin{array}{l}\text { Maeda et } \\
\text { al, } \\
2000^{20}\end{array}$ & $\begin{array}{l}\text { Patients } \\
\text { admitted for } \\
\text { heart failure } \\
\text { and surviving } \\
\text { to } 3 \text { months } \\
\text { (III-IV) }\end{array}$ & $\begin{array}{l}\text { Left ventricular } \\
\text { ejection } \\
\text { fraction }<45 \%\end{array}$ & 64 & Shionogi & $\begin{array}{l}\text { Cardiac } \\
\text { death or } \\
\text { admission to } \\
\text { hospital }\end{array}$ & $102(47)$ & 2.2 & Yes & Yes & $\begin{array}{l}\text { Not } \\
\text { reported }\end{array}$ & $\begin{array}{l}\text { Unadjusted } \\
\text { relative } \\
\text { risk }\end{array}$ & $\begin{array}{l}>240 \mathrm{pg} / \mathrm{ml} \\
\text { after } 3 \text { months } \\
\text { of treatment }\end{array}$ & $\begin{array}{l}\text { Relative risk } \\
3.8 \text { (2.4 to } 6.2)\end{array}$ \\
\hline
\end{tabular}

Follow-up was complete in all studies.

*The response to treatment has been divided into four quarters. Each group has been compared with the quarter that had the greatest reduction in BNP after treatment- - that is, patients with a reduction in their BNP value of more than $45 \%$.

continuous measure to estimate the relative risk of cardiac death $^{12}$ in the pooled estimate (again excluding the study by Bettencourt et al) gives a similar result of $37 \%$ (22\% to $54 \%$, heterogeneity $\left.\chi^{2}=10.2, \mathrm{df}=4, \mathrm{P}=0.037\right)$.

The studies that used dichotomous measures showed considerable variation in results, possibly because of the differences in the cut-offs used and because several of the studies estimated the relative risk of $\mathrm{BNP}$ to predict mortality or cardiovascular events unadjusted for other risk factors. They show, however, a consistently increased risk of either death or cardiovascular events with raised concetrations of BNP (tables 2 and 5). The pooled estimate from the studies using a continuous measure was consistent with the results seen of the largest study using a dichotomised measure-that is, a study of a subset of patients (4305 patients) from the valsartan heart failure trial (Val-HeFT) trial. ${ }^{13}$ This study showed in patients with BNP concentrations $>97 \mathrm{pg} / \mathrm{ml}$ a hazard ratio of death of 2.10 (1.79 to 2.42).

Patients whose BNP values fail to fall in response to treatment seem to be at particularly high risk of death or a cardiovascular event (tables 3 and 6). Models that included both initial measurements and measurements after treatment showed that the values after stabilisation on treatment were more significant predictors of death and further events than baseline values. $^{8} 1319202425$

\section{Asymptomatic patients}

BNP and NT-proBNP also predict mortality and cardiovascular events in asymptomatic patients (tables 7 and 8). Again, the studies used various methods for measuring the relation between BNP and mortality or cardiovascular events. The two largest studies used relatively low cut-off points $(\geq 17.9 \mathrm{pg} / \mathrm{ml}$ in the study by McDonagh et al, or $\geq 20.0 \mathrm{pg} / \mathrm{ml}$ in men and $\geq 23.3$ $\mathrm{pg} / \mathrm{ml}$ in women in the study by Wang et al). ${ }^{26}$ We could not assess from the data in the studies in this review whether the mortality risk associated with BNP is continuous or there is a threshold effect, but even using these relatively low cut-off levels of BNP, the relative risk of death doubled during the follow up periods of four and five years.

\section{Comparison of BNP with other prognostic markers}

Thirty five multivariable models included BNP or NT-proBNP to predict survival, cardiac death, readmission, or cardiac events; these included some models that did not estimate the relative risk or hazard ratio. ${ }^{31-38}$ In 23 of the 35 multivariable models, BNP or NT-proBNP had the smallest P value. In nine of the 35 models, BNP or NT-proBNP was the only predictor that reached significance; other prognostic markers contained no information beyond that provided by BNP. ${ }^{16} 19202223303137$ Many clinical features that have been shown to be associated with increased mortality, such as New York Heart Association class, serum creatinine concentration, lower systolic blood pressure, and higher heart rate $^{1}$ no longer reached significance in models that included BNP. In two models, BNP or NT-proBNP was not a significant predictor, and in both cases $\mathrm{N}$-terminal pro-atrial natriuretic peptide (N-proANP) reached significance. ${ }^{85} \mathrm{~N}$-proANP also excluded BNP and vice versa in the model developed by Wang et $\mathrm{al}^{26}$ but did not reach significance in 10 other models that included BNP.

Assessing the relative strength of prognostic markers on a continuous scale is difficult because of differences in the scale of each marker. We therefore estimated standardised hazard ratios (see bmj.com). Although theoretically this allows a better comparison between BNP and left ventricular ejection fraction as predictors, the results were quite inconsistent between studies (table 9). Another way to compare the predictive value of prognostic markers in heart failure is to compare the area under a receiver operating characteristic (ROC) curve for each variable, as this method also removes the scaling of the variable. We found only one study $(n=142)$ that estimated the predictive ability of factors for all cause mortality in advanced heart failure by using 
Table 7 B-type natriuretic peptide to predict survival in asymptomatic patients

\begin{tabular}{|c|c|c|c|c|c|c|c|c|c|c|c|c|}
\hline \multirow[b]{2}{*}{ Study } & \multirow[b]{2}{*}{ Population } & \multirow{2}{*}{$\begin{array}{l}\text { Excluded patients } \\
\text { with heart failure }\end{array}$} & \multirow{2}{*}{$\begin{array}{c}\text { Mean } \\
\text { age }\end{array}$} & \multirow[b]{2}{*}{ BNP test } & \multirow{2}{*}{$\begin{array}{l}\text { No of } \\
\text { participants } \\
\text { (events) }\end{array}$} & \multirow{2}{*}{$\begin{array}{l}\text { Mean } \\
\text { follow-up } \\
\text { in years }\end{array}$} & \multirow{2}{*}{$\begin{array}{c}\text { Population } \\
\text { cohort }\end{array}$} & \multirow{2}{*}{$\begin{array}{l}\text { Follow up } \\
\text { complete }\end{array}$} & \multicolumn{2}{|c|}{$\begin{array}{l}\text { Ascertainment of } \\
\text { outcome }\end{array}$} & \multirow{2}{*}{$\begin{array}{c}\text { BNP } \\
\text { measurement }\end{array}$} & \multirow{2}{*}{$\begin{array}{c}\text { Hazard ratio } \\
(95 \% \mathrm{Cl})\end{array}$} \\
\hline & & & & & & & & & Blinded & Objective & & \\
\hline $\begin{array}{l}\text { Wang et al, } \\
2004^{25}\end{array}$ & $\begin{array}{l}\text { Framingham } \\
\text { offspring study } \\
1995-8\end{array}$ & Yes & 59 & Shionogi & 3346 (119) & 5.2 & Yes & Yes & Yes & Yes & $\begin{array}{l}\text { Per } 1 \text { standard } \\
\text { deviation of } \\
\log _{10} \text { BNP }\end{array}$ & $\begin{array}{c}1.3 \\
(1.1 \text { to } 1.5)\end{array}$ \\
\hline $\begin{array}{l}\text { Wang et al, } \\
2004^{25}\end{array}$ & $\begin{array}{l}\text { Framingham } \\
\text { offspring study } \\
1995-8\end{array}$ & Yes & 59 & Shionogi & 3346 (119) & 5.2 & Yes & Yes & Yes & Yes & $\begin{array}{l}>80 \text { th } \\
\text { percentile* }\end{array}$ & $\begin{array}{c}1.6 \\
(1.1 \text { to } 2.4)\end{array}$ \\
\hline $\begin{array}{l}\text { McDonagh } \\
\text { et al, } \\
2001^{26}\end{array}$ & $\begin{array}{l}\text { Random sample of } \\
\text { Glasgow population } \\
\text { aged } 25-74 \text { who } \\
\text { participated in } \\
\text { MONICA risk factor } \\
\text { survey, 1992-93 }\end{array}$ & No & 50 & Peninsula & $1252(80)$ & 4 & $\begin{array}{c}\text { Subset } \\
\text { of total } \\
1640 \\
\text { patients }\end{array}$ & Yes & $\begin{array}{l}\text { Not } \\
\text { reported }\end{array}$ & Yes & $\geq 17.9 \mathrm{pg} / \mathrm{ml}$ & $\begin{array}{c}2.2 \\
(1.2 \text { to } 3.8)\end{array}$ \\
\hline $\begin{array}{l}\text { Groenning } \\
\text { et al, } \\
2004^{27}\end{array}$ & $\begin{array}{l}\text { People aged } 50 \text { to } \\
90 \text { recruited from } \\
\text { four general } \\
\text { practices in } \\
\text { Copenhagen }\end{array}$ & No & $\begin{array}{l}\text { Median } \\
\quad 67\end{array}$ & $\begin{array}{l}\text { NT-proBNP } \\
\text { (in-house) }\end{array}$ & $672(32)$ & Median 2.2 & Yes & NR & Yes & Yes & $\begin{array}{l}\text { NT-proBNP } \\
\text { Per } \log _{10} \\
\mathrm{pmol} / /\end{array}$ & $\begin{array}{c}5.7 \\
(1.4 \text { to } 23.2) \dagger\end{array}$ \\
\hline $\begin{array}{l}\text { Wallen et } \\
\text { al, } \\
1997^{28}\end{array}$ & $\begin{array}{l}\text { People aged } 85 \text { in } \\
\text { Gothenburg, study }\end{array}$ & Total=No & 85 & Shionogi & 541 (214) & 5 & Yes & $\begin{array}{c}\text { Not } \\
\text { reported }\end{array}$ & $\begin{array}{c}\text { Not } \\
\text { reported }\end{array}$ & Yes & $\begin{array}{l}\text { Per } \log _{10} \\
\mathrm{pmol} / \mathrm{l}\end{array}$ & $\begin{array}{c}1.3 \\
(1.1 \text { to } 1.5)\end{array}$ \\
\hline $\begin{array}{l}\text { Wallen et } \\
\text { al, } \\
1997^{28}\end{array}$ & $\begin{array}{l}\text { People aged } 85 \text { in } \\
\text { Gothenburg, study }\end{array}$ & $\begin{array}{l}\text { Subset of patients in } \\
\text { whom a diagnosis } \\
\text { of heart failure was } \\
\text { excluded=yes }\end{array}$ & 85 & Shionogi & $\begin{array}{l}209 \text { (not } \\
\text { reported) }\end{array}$ & 5 & Yes & $\begin{array}{c}\text { Not } \\
\text { reported }\end{array}$ & $\begin{array}{c}\text { Not } \\
\text { reported }\end{array}$ & Yes & $\begin{array}{l}\text { Per } \log _{10} \\
\text { pmol/ }\end{array}$ & $\begin{array}{c}1.4 \\
(1.0 \text { to } 1.8)\end{array}$ \\
\hline $\begin{array}{l}\text { Ueda et al, } \\
2003^{29}\end{array}$ & $\begin{array}{l}\text { People aged }>80 \\
\text { who participated in } \\
\text { community health } \\
\text { screening } \\
\text { programmes in } \\
\text { Tokyo }\end{array}$ & Yes & 86 & Shionogi & $111(21)$ & 2 & No & Yes & No & Yes & Per $100 \mathrm{pg} / \mathrm{ml}$ & $\begin{array}{c}2.0 \\
(1.4 \text { to } 2.6)\end{array}$ \\
\hline
\end{tabular}

The outcome in all studies was death.

The model used in all studies was adjusted Cox regression.

* $20.0 \mathrm{pg} / \mathrm{ml}$ in men; $23.3 \mathrm{pg} / \mathrm{ml}$ in women.

tConfidence interval calculated by authors from published $\mathrm{P}$ value.

ROC curves. ${ }^{16}$ The areas under the ROC curve were 0.738 for NT-proBNP, 0.640 for left ventricular ejection fraction, 0.650 for peak oxygen uptake $\left(\mathrm{VO}_{2}\right)$, and 0.654 for the heart failure survival score, indicating that NT-proBNP has the greatest predictive value.

The strength of prognostic variables in models may also be confounded by decisions on treatment. For example, patients with low left ventricular ejection fractions may be treated more aggressively by clinicians, thereby diluting some of the prognostic value of left ventricular ejection fraction. However, BNP remained a significant predictor of prognosis, even in models in which treatment was included as a variable $7^{7132730323638} \mathrm{BNP}$ may also add to the prognostic information of left ventricular ejection fractions. In the cohort of participants in the 1992 multinational

Table 8 B-type natriuretic peptide to predict cardiovascular events in asymptomatic patients

\begin{tabular}{|c|c|c|c|c|c|c|c|c|c|c|c|}
\hline \multirow[b]{2}{*}{$\underline{\text { Study }}$} & \multirow[b]{2}{*}{ Population } & \multirow{2}{*}{$\begin{array}{c}\text { Excluded } \\
\text { patients } \\
\text { with heart } \\
\text { failure }\end{array}$} & \multirow{2}{*}{$\begin{array}{c}\text { Mean } \\
\text { age }\end{array}$} & \multirow[b]{2}{*}{ Outcome } & \multirow{2}{*}{$\begin{array}{l}\text { No of } \\
\text { participants } \\
\text { (events) }\end{array}$} & \multirow{2}{*}{$\begin{array}{c}\text { Mean } \\
\text { follow-up in } \\
\text { years }\end{array}$} & \multirow{2}{*}{$\begin{array}{l}\text { Population } \\
\text { cohort }\end{array}$} & \multicolumn{2}{|c|}{$\begin{array}{c}\text { Ascertainment of } \\
\text { outcome }\end{array}$} & \multirow{2}{*}{$\begin{array}{c}\text { BNP } \\
\text { measurement } \\
\end{array}$} & \multirow{2}{*}{$\begin{array}{c}\text { Hazard ratio } \\
(95 \% \mathrm{Cl})\end{array}$} \\
\hline & & & & & & & & Blinded & Objective & & \\
\hline $\begin{array}{l}\text { Wang et al, } \\
2004^{25}\end{array}$ & $\begin{array}{l}\text { Framingham offspring study } \\
\text { without heart failure }\end{array}$ & Yes & 59 & $\begin{array}{l}\text { First major } \\
\text { cardiovascular } \\
\text { event }\end{array}$ & 3036 (79) & 5.2 & Yes & Yes & Yes & $\begin{array}{l}\text { Per } 1 \text { standard } \\
\text { deviation of } \\
\log _{10} \text { BNP }\end{array}$ & $\begin{array}{c}1.3 \\
(1.0 \text { to } 1.6)\end{array}$ \\
\hline $\begin{array}{l}\text { Wang et al, } \\
2004^{25}\end{array}$ & $\begin{array}{l}\text { Framingham offspring study } \\
\text { without heart failure }\end{array}$ & Yes & 59 & $\begin{array}{l}\text { First major } \\
\text { cardiovascular } \\
\text { event }\end{array}$ & 3036 (79) & 5.2 & Yes & Yes & Yes & $\begin{array}{l}>80 \text { th } \\
\text { percentile }\end{array}$ & $\begin{array}{c}1.8 \\
(1.1 \text { to } 2.9)\end{array}$ \\
\hline $\begin{array}{l}\text { Groenning, } \\
2004^{27}\end{array}$ & $\begin{array}{l}\text { People aged } 50-90 \text {, } \\
\text { recruited from four general } \\
\text { practices in Copenhagen }\end{array}$ & No & $\begin{array}{l}\text { Median } \\
\quad 67\end{array}$ & $\begin{array}{l}\text { Admission with } \\
\text { heart failure }\end{array}$ & $672(20)$ & Median 2.2 & Invited to attend & Yes & Yes & $\begin{array}{l}\text { NT-pro- } \\
\text { BNP per } \log _{10} \\
\text { pmol/l }\end{array}$ & $\begin{array}{c}13.8 \\
(1.7 \text { to } 114.8) \dagger\end{array}$ \\
\hline $\begin{array}{l}\text { Groenning, } \\
2004^{27}\end{array}$ & $\begin{array}{l}\text { People aged } 50-90 \text {, } \\
\text { recruited from four general } \\
\text { practices in Copenhagen }\end{array}$ & No & $\begin{array}{l}\text { Median } \\
\quad 67\end{array}$ & $\begin{array}{l}\text { Other cardiac } \\
\text { admissions }\end{array}$ & $672(57)$ & Median 2.2 & Invited to attend & Yes & Yes & $\begin{array}{l}\text { NT-pro-BNP } \\
\text { per } \log _{10} \mathrm{pmol} / \mathrm{l}\end{array}$ & $\begin{array}{c}3.7 \\
(1.3 \text { to } 10.6) \dagger\end{array}$ \\
\hline $\begin{array}{l}\text { Ueda et al, } \\
2003^{29}\end{array}$ & $\begin{array}{l}\text { People aged }>80 \text { who } \\
\text { participated in community } \\
\text { health screening } \\
\text { programmes in Tokyo } \\
\text { (excluding patients with } \\
\text { heart failure or heart } \\
\text { disease) }\end{array}$ & Yes & 86 & Cardiac admission & 111 (8) & 2 & Yes & No & Yes & per $100 \mathrm{pg} / \mathrm{ml}$ & $\begin{array}{c}2.6 \\
(1.4 \text { to } 4.4)\end{array}$ \\
\hline
\end{tabular}

Follow-up was complete in all studies except for that by Groenning et al, for which it was not reported.

The model used in all studies was adjusted Cox regression.

All studies used the Shionogi test to measure BNP except that by Groenning et al, which used NT-proBNP (in house)

*20.0 pg/ml in men; $23.3 \mathrm{pg} / \mathrm{ml}$ in women.

†Confidence interval calculated by authors from published $P$ value. 
Table 9 Standardised hazard ratios for B type natriuretic peptide and left ventricular ejection fraction

\begin{tabular}{|c|c|c|c|c|c|c|c|c|c|}
\hline Study & $\mathbf{N}$ & Inclusion criteria & $\begin{array}{l}\text { Measurement } \\
\text { of BNP* }\end{array}$ & $\begin{array}{l}\text { Hazard ratio for BNP } \\
\text { as continuous } \\
\text { variable in } \\
\text { multivariable model }\end{array}$ & $\begin{array}{l}\text { Standard } \\
\text { deviation } \\
\text { of BNP }\end{array}$ & $\begin{array}{l}\text { Standardised } \\
\text { hazard ratio of } \\
\text { BNP }\end{array}$ & $\begin{array}{c}\text { Hazard ratio for left } \\
\text { ventricular ejection } \\
\text { fraction as continuous } \\
\text { variable in multivariable } \\
\text { model }\end{array}$ & $\begin{array}{c}\text { Standard } \\
\text { deviation of left } \\
\text { ventricular } \\
\text { ejection fraction }\end{array}$ & $\begin{array}{l}\text { Standardised } \\
\text { hazard ratio of } \\
\text { left ventricular } \\
\text { ejection fraction }\end{array}$ \\
\hline $\begin{array}{c}\text { Tsutamoto et } \\
\text { al, } 1999^{7}\end{array}$ & 290 & $\begin{array}{l}\text { Patients undergoing cardiac } \\
\text { catheterisation, left ventricular } \\
\text { ejection fraction }<45 \%\end{array}$ & BNP & 1.004 & $230 \dagger$ & 2.55 & - & 8.5 & - \\
\hline $\begin{array}{l}\text { Imamura et } \\
\text { al, } 2001^{12}\end{array}$ & 171 & $\begin{array}{l}\text { Patients enrolled in study of } \\
\text { I-123-meta-iodobenzylguanidine } \\
\text { left ventricular ejection } \\
\text { fraction }<40 \%\end{array}$ & e & 1.005 & 188 & 2.51 & 0.848 & 10 & 5.20 \\
\hline $\begin{array}{l}\text { Bettencourt et } \\
\text { al, } 2000^{9}\end{array}$ & 139 & $\begin{array}{l}\text { Patients with mild to } \\
\text { moderate heart failure } \\
\text { determined by clinical } \\
\text { assessment }\end{array}$ & BNP & 1.0001 & 429 & 1.04 & - & 13 & - \\
\hline $\begin{array}{l}\text { Ueda et al, } \\
2003^{29}\end{array}$ & 111 & $\begin{array}{l}\text { Patients aged }>80 \text { in health } \\
\text { screening programme and } \\
\text { without heart failure }\end{array}$ & BNP & 1.007 & 99 & 1.95 & - & Not reported & - \\
\hline $\begin{array}{l}\text { Tsutamoto et } \\
\text { al, } 2001^{10}\end{array}$ & 96 & $\begin{array}{l}\text { Patients with heart failure } \\
\text { in outpatient clinic, left } \\
\text { ventricular ejection fraction } \\
<45 \%\end{array}$ & BNP & 1.002 & 317 & 1.53 & 0.955 & 9.6 & 1.48 \\
\hline $\begin{array}{l}\text { Tsutamoto et } \\
\text { al, } 1997^{11}\end{array}$ & 85 & $\begin{array}{l}\text { Patients admitted with heart } \\
\text { failure, left ventricular } \\
\text { ejection fraction }<45 \%\end{array}$ & BNP & 1.003 & 286 & 2.35 & - & 10.1 & - \\
\hline $\begin{array}{c}\text { Koglin et al, } \\
2001^{21}\end{array}$ & 78 & $\begin{array}{l}\text { Patients referred to heart } \\
\text { failure clinic, no left } \\
\text { ventricular ejection fraction } \\
\text { criteria }\end{array}$ & BNP & 1.004 & $230 \dagger$ & 2.51 & - & Not reported & - \\
\hline $\begin{array}{c}\text { Tamura et al, } \\
2001^{22}\end{array}$ & 48 & $\begin{array}{l}\text { Patients admitted for heart } \\
\text { failure determined by } \\
\text { clinical assessment }\end{array}$ & Log BNP & 2.656 & $0.66 \ddagger$ & 1.91 & 0.973 & 4.4 & 1.13 \\
\hline
\end{tabular}

*Whether BNP was measured as a normal or log BNP.

†SD not reported in study, taken from Val-HeFT trial $(n=3618) .^{13}$

FSD not reported in study, taken from Berger et al study $(\mathrm{n}=452) .{ }^{30}$

monitoring of trends and determinants in cardiovascular disease (MONICA) risk factor survey in Glasgow, four year mortality from all causes was determined for patients with and without left ventricular dysfunction (defined as left ventricular ejection fraction $\leq 40 \%$ and $>40 \%$ ) and raised and normal concentrations of BNP (defined as $\geq 17.9 \mathrm{pg} / \mathrm{ml}$ and $<17.9 \mathrm{pg} / \mathrm{ml}$ ). ${ }^{27}$ The risk of mortality for the group with raised $\mathrm{BNP}$ alone was $7 \%$; with reduced left ventricular ejection fractions alone, $8 \%$; and with the two factors combined, 17\%, indicating an apparently additive risk (table 9).

\section{Comparison of BNP with NT-proBNP}

BNP was directly compared with NT-proBNP in only one model. In the multivariable analysis, both log BNP and log NT-proBNP reached significance in univariate analysis, but only log BNP remained significant in the multivariable analysis. ${ }^{30}$

\section{Discussion}

BNP was a consistently significant prognostic indicator in patients diagnosed with heart failure and in asymptomatic patients in the studies under review. The prognostic information seems to be at least additive with that of left ventricular ejection fraction, and BNP should be used to assess prognosis in patients with heart failure.

\section{Defining heart failure}

If $\mathrm{BNP}$ predicts prognosis, including in patients not diagnosed with heart failure, it raises important questions concerning the way that heart failure is defined and diagnosed. In most recent trials of treatment and in studies of diagnostic accuracy, the reference standard for the diagnosis of heart failure has been systolic function as measured by left ventricular ejection fraction. This is despite the fact that it is recognised that $20-50 \%$ of patients with heart failure have preserved systolic function. ${ }^{39}$ Currently, no criteria are agreed for how to categorise patients with "diastolic dysfunction." BNP is a strong indicator of cardiac risk and may therefore be a better way of identifying the cohort of patients who would benefit from treatment. This hypothesis could be tested by a trial of heart failure treatment in patients with discordant results for BNP guided diagnosis compared with standard echocardiographic or clinical diagnosis. This raises further questions. It would not be difficult to enrol patients in a trial of treatment who have a raised BNP measurement but normal left ventricular function. Is it also possible that patients with a low left ventricular ejection fraction but a normal BNP do not benefit from treatment?

\section{Cut-off values for BNP}

The question also arises of what should be considered a "normal" value of BNP. The risk of death and cardiovascular events seems to rise with even small values of BNP. In the studies in asymptomatic patients by Wang et al and McDonagh et al, ${ }^{26}$ the relative risk of death and cardiovascular events was doubled at values well below those currently considered diagnostic for heart failure, at $80-100 \mathrm{pg} / \mathrm{ml} .{ }^{17}$ At what measurement might the benefits of treatment be effective and cost effective?

\section{Monitoring heart failure}

The fact that patients with a raised BNP value after treatment, whether in hospital or as outpatients, were at high risk of a further event also implies that BNP may be useful to monitor treatment response and guide decisions on further treatment. Two small trials have proposed that using BNP to guide treatment results in fewer cardiac events than traditional clinical assessment, ${ }^{40}{ }^{41}$ but these results are preliminary and need confirmation in larger clinical trials. 


\section{What is already known on this topic}

Factors shown to be predictors of mortality in heart failure are increasing age, a history of diabetes mellitus or renal dysfunction, higher New York Heart Association class, lower left ventricular ejection fraction, lower sodium concentrations, lower body mass index, lower blood pressure, the presence of ankle oedema, and lower quality of life scores

The clinical assessment of prognosis in heart failure is difficult, however, and none of the above factors are strong predictors of survival or cardiovascular events

\section{What this study adds}

B-type natriuretic peptide is a strong prognostic indicator for patients with heart failure at all stages of disease and seems to be a better predictor of survival than many traditional prognostic indicators, such as New York Heart Association class, serum creatinine, and possibly left ventricular ejection fraction

The relative risk of death increases by about $35 \%$ for each 100 $\mathrm{pg} / \mathrm{ml}$ increase in BNP in patients with heart failure patients

Raised BNP values also predict survival in patients not known to have heart failure, with the risk doubled in patients with a BNP value $>20 \mathrm{pg} / \mathrm{ml}$

\section{Limitations}

Despite the abundance of studies, this review has several limitations. In part this is because systematic reviews of prognostic studies are hampered by the standard of reporting of the original studies. Finding all prognostic studies is difficult as they are not tagged as such in Medline, and finding negative studies-that is, studies where the variable was considered but did not reach significance-is particularly difficult. Many of the studies did not report on features that would ensure objective and unbiased estimates of prognostic indicators. In addition, the true impact on prognosis may be less than estimated from these studies because studies that did not show a significant effect have possibly not been published.

BNP is a powerful prognostic indicator for patients with heart failure at all stages of disease. Both initial values and values after starting treatment are important indicators of disease severity.

Contributors: The idea for this study arose from a previous review of diagnostic accuracy studies. JAD designed the study, and JAD and EP assessed the studies for inclusion and extracted data. PPG and AD provided advice on the statistical analysis and interpretation of the studies. JAD, PPG, and $\mathrm{AD}$ drafted the paper. JAD is the guarantor.

Funding source: National Health and Medical Research Council programme grant 211205: Screening and Test Evaluation Programme (STEP) grant.

Competing interests: None declared.

Bouvy ML, Heerdink ER, Leufkens HG, Hoes AW. Predicting mortality in patients with heart failure: a pragmatic approach. Heart 2003;89:605-9.

2 Cowie MR, Wood DA, Coats AJ, Thompson SG, Suresh V, Poole-Wilson PA, et al. Survival of patients with a new diagnosis of heart failure: a population based study. Heart 2000;83:505-10.

3 Scrutinio D, Lagioia R, Ricci A, Clemente M, Boni L, Rizzon P. Prediction of mortality in mild to moderately symptomatic patients with left ventricular dysfunction. The role of the New York Heart Association classification, cardiopulmonary exercise testing. of the New York Heart Association classification, cardiopulmonary exercise testing,
two-dimensional echocardiography and Holter monitoring. Eur Heart J 1994;15:1089two-

4 Aaronson KD, Schwartz JS, Chen TM, Wong KL, Goin JE, Mancini DM. Development and prospective validation of a clinical index to predict survival in ambulatory patients referred for cardiac transplant evaluation. Circulation 1997;95:2660-7.
5 Doust JA, Glasziou PP, Pietrzak E, Dobson AJ. A systematic review of the diagnostic accuracy of natriuretic peptides for heart failure. Arch Intern Med 2004;164:1978-84.

6 Altman DG. Systematic reviews of evaluations of prognostic variables. BMJ 2001;323:224-8.

7 Tsutamoto T, Wada A, Maeda K, Hisanaga T, Mabuchi N, Hayashi M, et al. Plasma brain natriuretic peptide level as a biochemical marker of morbidity and mortality in patients with asymptomatic or minimally symptomatic left ventricular dysfunction. Comparison with plasma angiotensin II and endothelin-1. Eur Heart J 1999;20:1799-807.

8 Wijeysundera HC, Hansen MS, Stanton E, Cropp AS, Hall C, Dhalla NS, et al. Neurohormones and oxidative stress in nonischemic cardiomyopathy: relationship to survival and the effect of treatment with amlodipine. Am Heart J 2003;146:291-7.

9 Bettencourt P, Ferreira A, Dias P, Pimenta J, Frioes F, Martins L, et al. Predictors of prognosis in patients with stable mild to moderate heart failure.J Card Fail 2000;6:30613.

10 Tsutamoto T, Wada A, Maeda K, Mabuchi N, Hayashi M, Tsutsui T, et al. Relationship between plasma levels of cardiac natriuretic peptides and soluble Fas: plasma soluble Fas as a prognostic predictor in patients with congestive heart failure. J Card Fail 2001;7:322-8.

11 Tsutamoto T, Wada A, Maeda K, Hisanaga T, Maeda Y, Fukai D, et al. Attenuation of compensation of endogenous cardiac natriuretic peptide system in chronic heart failure: prognostic role of plasma brain natriuretic peptide concentration in patients with ure: prognostic role of plasma brain natriuretic peptide concentration in patient
chronic symptomatic left ventricular dysfunction. Circulation 1997;96:509-16.

12 Imamura Y, Fukuyama T, Mochizuki T, Mivagawa M, Watanabe K. Prognostic value of iodine-123-metaiodobenzylguanidine imaging and cardiac natriuretic peptide levels in patients with left ventricular dysfunction resulting from cardiomyopathy. Jpn Circ J 2001;65:155-60

13 Anand IS, Fisher LD, Chiang YT, Latini R, Masson S, Maggioni AP, et al. Changes in brain natriuretic peptide and norepinephrine over time and mortality and morbidity in the Valsartan Heart Failure Trial (Val-HeFT). Circulation 2003;107:1278-83.

14 Richards AM, Doughty R, Nicholls MG, MacMahon S, Sharpe N, Murphy J, et al. Plasma N-terminal pro-brain natriuretic peptide and adrenomedullin: prognostic utility and prediction of benefit from carvedilol in chronic ischemic left ventricular dysfunction. Australia-New Zealand Heart Failure Group. I Am Coll Cardiol dysfunction. Au

15 Vrtovec B, Delgado R, Zewail A, Thomas CD, Richartz BM, Radovancevic B. Prolonged QTc interval and high B-type natriuretic peptide levels together predict mortality in patients with advanced heart failure. Circulation 2003;107:1764-9.

16 Gardner RS, Ozalp F, Murday AJ, Robb SD, McDonagh TA. N-terminal pro-brain natriuretic peptide. A new gold standard in predicting mortality in patients with advanced heart failure. Eur Heart J 2003;24:1735-43.

17 Harrison A, Morrison LK, Krishnaswamy P, Kazanegra R, Clopton P, Dao Q, et al. B-type natriuretic peptide predicts future cardiac events in patients presenting to the emergency department with dyspnea. Ann Emerg Med 2002;39:131-8.

$18 \mathrm{Yu}$ CM, Sanderson JE. Plasma brain natriuretic peptide-an independent predictor of cardiovascular mortality in acute heart failure. Eur J Heart Fail 1999;1:59-65.

19 Matsui T, Tsutamoto T, Maeda K, Kusukawa J, Kinoshita M. Prognostic value of repeated 123I-metaiodobenzylguanidine imaging in patients with dilated cardiomyopathy with congestive heart failure before and after optimized treatmentscomparison with neurohumoral factors. Circ J 2002;66:537-43.

20 Maeda K, Tsutamoto T, Wada A, Mabuchi N, Hayashi M, Tsutsui T, et al. High levels of plasma brain natriuretic peptide and interleukin-6 after optimized treatment for heart failure are independent risk factors for morbidity and mortality in patients with congestive heart failure. J Am Coll Cardiol 2000;36:1587-93.

21 Koglin J, Pehlivanli S, Schwaiblmair M, Vogeser M, Cremer P, vonScheidt W. Role of brain natriuretic peptide in risk stratification of patients with congestive heart failure.J Am Coll Cardiol 2001;38:1934-41.

22 Tamura K, Takahashi N, Nakatani Y, Onishi S, Iwasaka T. Prognostic impact of plasma brain natriuretic peptide for cardiac events in elderly patients with congestive heart failure. Gerontology 2001;47:46-51

23 Ishii J, Nomura M, Nakamura Y, Naruse H, Mori Y, Ishikawa T, et al. Risk stratification using a combination of cardiac troponin $\mathrm{T}$ and brain natriuretic peptide in patients hospitalized for worsening chronic heart failure. Am J Cardiol 2002;89:691-5.

24 Cheng V, Kazanagra R, Garcia A, Lenert L, Krishnaswamy P, Gardetto N, et al. A rapid bedside test for B-type peptide predicts treatment outcomes in patients admitted for decompensated heart failure: a pilot study. J Am Coll Cardiol 2001;37:386-91.

25 Wang TJ, Larson MG, Levy D, Benjamin EJ, Leip EP, Omland T, et al. Plasma natriuretic peptide levels and the risk of cardiovascular events and death. $N$ Engl J Med 2004:350:655-63.

26 McDonagh TA, Cunningham AD, Morrison CE, McMurray JJ, Ford I, Morton JJ, et al. Left ventricular dysfunction, natriuretic peptides, and mortality in an urban population. Heart 2001;86:21-6.

27 Groenning BA, Raymond I, Hildebrandt PR, Nilsson JC, Baumann M, Pedersen F Diagnostic and prognostic evaluation of left ventricular systolic heart failure by plasma $\mathrm{N}$-terminal pro-brain natriuretic peptide concentrations in a large sample of the general population. Heart 2004;90:297-303.

28 Wallen T, Landahl S, Hedner T, Nakao K, Saito Y. Brain natriuretic peptide predicts mortality in the elderly. Heart 1997;77:264-7.

29 Ueda R, Yokouchi M, Suzuki T, Otomo E, Katagiri T. Prognostic value of high plasma brain natriuretic peptide concentrations in very elderly persons. Am J Med 2003;114:266-70.

30 Berger R, Huelsman M, Strecker K, Bojic A, Moser P, Stanek B, et al. B-type natriuretic peptide predicts sudden death in patients with chronic heart failure. Circulation 2002;105:2392-7.

31 Bettencourt P, Ferreira S, Azevedo A, Ferreira A. Preliminary data on the potential usefulness of B-type natriuretic peptide levels in predicting outcome after hospital discharge in patients with heart failure. Am J Med 2002;113:215-9.

32 Hulsmann M, Berger R, Sturm B, Bojic A, Woloszczuk W, Bergler-Klein J, et al. Prediction of outcome by neurohumoral activation, the six-minute walk test and the Minnesota Living with Heart Failure Questionnaire in an outpatient cohort with congestive sota Living with Heart Failure Questionn

33 Ishii J, Cui W, Kitagawa F, Kuno T, Nakamura Y, Naruse H, et al. Prognostic value of combination of cardiac troponin T and B-type natriuretic peptide after initiation of treatment in patients with chronic heart failure. Clin Chem 2003;49:2020-6. 
34 Isnard R, Pousset F, Chafirovskaia O, Carayon A, Hulot JS, Thomas D, et al. Combination of B-type natriuretic peptide and peak oxygen consumption improves risk stratification in outpatients with chronic heart failure. Am Heart J 2003;146:729-35.

35 Selvais PL, Robert A, Ahn S, van Linden F, Ketelslegers JM, Pouleur H, et al. Direc comparison between endothelin-1, N-terminal proatrial natriuretic factor, and brain natriuretic peptide as prognostic markers of survival in congestive heart failure. J Card Fail 2000;6:201-7.

36 Stanek B, Frey B, Hulsmann M, Berger R, Sturm B, Strametz-Juranek J, et al. Prognostic evaluation of neurohumoral plasma levels before and during beta-blocker therapy in advanced left ventricular dysfunction. J Am Coll Cardiol 2001;38:436-42.

37 Tsutsui T, Tsutamoto T, Wada A, Maeda K, Mabuchi N, Havashi M, et al. Plasma oxidized low-density lipoprotein as a prognostic predictor in patients with chronic coxidized low-density lipoprotein as a prognostic predict

38 Zugck C, Haunstetter A, Kruger C, Kell R, Schellberg D, Kubler W, et al. Impact of betablocker treatment on the prognostic value of currently used risk predictors in congestive heart failure. J Am Coll Cardiol 2002;39:1615-22.

39 Jessup M, Brozena S. Heart failure. N Engl J Med 2003;348:2007-18.

40 Murdoch DR, McDonagh TA, Byrne J, Blue L, Farmer R, Morton JJ, et al. Titration of vasodilator therapy in chronic heart failure according to plasma brain natriuretic peptide concentration: randomized comparison of the hemodynamic and neuroendocrine effects of tailored versus empirical therapy. Am Heart J 1999;138(6 Pt 1):1126-32.
41 Troughton RW, Frampton CM, Yandle TG, Espiner EA, Nicholls MG, Richards AM. Treatment of heart failure guided by plasma aminoterminal brain natriuretic peptide (N-BNP) concentrations. Lancet 2000;355:1126-30.

(Accepted 8 February 2005)

Centre for General Practice, School of Medicine, University of Queensland, Herston Road, Herston, Qld 4006, Australia

Jenny A Doust senior research fellow

School of Population Health, University of Queensland

Eva Pietrzak senior research officer

Annette Dobson professor of biostatistics

Centre for Evidence-Based Medicine, Department of Primary Health Care,

University of Oxford, Oxford

Paul Glasziou director

Correspondence:J Doust j.doust@sph.uq.edu.au

bmj.com 2005;330:625 